\title{
Staphylococcus hyicus (Sompolinsky 1953) comb. nov. and Staphylococcus hyicus subsp. chromogenes subsp. nov.
}

\author{
L. A. DEVRIESE, ${ }^{1}$ V. HÁJEK, ${ }^{2}$ P. OEDING, ${ }^{2}$ S. A. MEYER, ${ }^{3}$ AND K. H. SCHLEIFER ${ }^{3}$ \\ Faculty of Veterinary Medicine, Casinoplein, B-9000 Gent, Belgium ${ }^{1}$; Microbiological Institute, Palacky \\ University, Olomouc, Czechoslovakia ${ }^{2}$; The Gade Institute, Department of Microbiology, University of \\ Bergen, Bergen, Norway; Lehrstuhl für Mikrobiologie, Technische Universität München, 8 \\ Munich 19, Germany ${ }^{3}$
}

\begin{abstract}
Although the name Staphylococcus hyicus has appeared in the literature, it has never been validly published. Supportive evidence is given for the transfer of Micrococcus hyicus Sompolinsky to the genus Staphylococcus, and the name Staphylococcus hyicus (Sompolinsky) comb. nov. is proposed. A description of this organism is given on the basis of a taxonomic analysis of 168 strains of this species isolated from swine with infectious epidermitis, from the skin and nares of healthy pigs and poultry, and from cows with mastitis. One hundred thirty-two strains which produced unpigmented colonies and a heat-stable nuclease were placed in the type subspecies $S$. hyicus subsp. hyicus subsp. nov. Thirty-six pigmented strains were placed in the subspecies $S$. hyicus subsp. chromogenes subsp. nov. Strain NCTC 10350 (= CCM 2368 = ATCC $11249=$ D. Sompolinsky no. 1) is here designated the type strain of $S$. hyicus and of S. hyicus subsp. hyicus, and strain NCTC 10530 (= A. C. Baird Parker CBCC 1462) is designated the type strain of $S$. hyicus subsp. chromogenes. A scheme for the differentiation of S. hyicus from certain other Staphylococcus species is included.
\end{abstract}

In 1950, Sompolinsky described a gram-positive coccus isolated from pigs with exudative epidermitis, and he succeeded in reproducing the disease by inoculating cultures of this organism into apparently healthy pigs (25). He named his strains Micrococcus hyicus and gave a description of their most prominent characters (26). After a later redefinition of the genera Staphylococcus and Micrococcus (10), it was realized that these bacteria were not members of the genus Micrococcus. Baird-Parker (3) examined one strain of $M$. hyicus and found that its characteristics were identical to those of his Staphylococcus subgroup III. However, he did not make a formal proposal of a new combination, and he continued to use the name $M$. hyicus in his paper (3). The name Staphylococcus hyicus came into general use in veterinary publications but apparently was never formally proposed. The 1974 edition of Bergey's Manual (4) lists $M$. hyicus as belonging to $S$. epidermidis biotype 2. One of the objectives of the present paper is to effect the valid publication of the name Staphylococcus hyicus.

The above-mentioned situation was further complicated by the irregular, often negative, but sometimes delayed positive, results which may be obtained with $M$. hyicus strains in tube coagulase tests with different kinds of plasma (1, $9,27,28)$. Furthermore, the strains produce a heat-resistant nuclease, a characteristic gener- ally accepted as a unique feature of $S$. aureus $(4,19)$. Strains isolated from bovine mastitis and poultry skin which have been referred to as coagulase-positive members of $S$. epidermidis subgroup 2 (5) and $S$. aureus avian biotype 2 (21), respectively, were found to be indistinguishable from $\boldsymbol{M}$. hyicus strains from pigs (9). The poultry and swine strains occur frequently as skin inhabitants $(8,9,21)$.

These findings, coupled with the fact that a new and more restrictive description has now been given to $S$. epidermidis (23), led us to reexamine the taxonomic position of $M$. hyicus.

\section{MATERIALS AND METHODS}

Bacterial strains. The designations, origins, and references containing the first descriptions of the strains studied are listed in Table 1 . With few exceptions, the strains were obtained from different farms. The type strains of various Staphylococcus species obtained from the Czechoslovak Collection of Microorganisms (CCM), J. E. Purkyne University, Brno, were included in the test series for comparative purposes.

Methods. Cell and colony characteristics; the production of catalase, clumping factor, heat-stable and heat-labile nucleases, hyaluronidase, and phosphatase; hemolysis; hippurate hydrolysis; nitrate reduction; hydrolysis of polysorbates and gelatin; anaerobic growth in thioglycolate medium; and final $\mathrm{pH}$ in a fluid glucose medium were determined as described previously (9). 
Twenty strains from different sources were examined for motility by the hanging-drop method.

The following tests were also carried out as previously described (11): oxidase production; benzidine test; coagulase activity on rabbit plasma; growth on Simmons citrate medium; production of arginine dihydrolase, caseinase, hydrogen sulfide, indole, phenylalanine deaminase, and fibrinolysin; hydrolysis of esculin; reduction of tellurite; and susceptibility to phages used for typing staphylococci from human and bovine sources.

Minimal inhibitory concentrations (MICs) of varjous antibiotics, lysostaphin (Schwarz/Mann; lot no. AZ-1975; specific activity, $237 \mathrm{U} / \mathrm{mg}$ ), lysozyme from egg white (Sigma Chemical Co., grade I), and $\mathrm{NaCl}$ were determined by the agar dilution technique (29), using overnight broth cultures diluted 100 -fold as inocula and tryptone soy agar (Oxoid Ltd.) as the test medium. This medium was substituted by Wellcotest medium (Wellcome Research Laboratories) when testing for susceptibility to sulfamethoxazole and trimethoprim. Penicillinase activity was determined by the agar diffusion test (30).

Acid production from sugars and sugar alcohols was determined on peptone-free ASS medium (24) modified to contain $0.5 \%$ yeast extract (Difco Laboratories). Negative cultures were retested in phenol red broth (Difco). The tests were observed for 3 days on ASS plate medium and for 5 days on phenol red broth. All sugars were used at a $1 \%$ concentration, and any evidence of $\mathrm{pH}$ decline was recorded as a positive reaction. Acetoin production was determined by the method of Davis and Hoyling (6). Lipolytic activity was determined on tributyrin agar (Oxoid) after 2 days of incubation at $37^{\circ} \mathrm{C}$. Urease production was tested for on Christensen urea agar (Oxoid) with incubation for 14 days.

Serological determination of teichoic acid and protein A was performed by an agar precipitation technique previously described (9). In addition to the reference systems used by Devriese and Oeding (9), the strains were tested against a specific system consisting of strain VA308 and the homologous rabbit antiserum. Cell wall peptidoglycan type and configuration of lactic acid were determined as described by Schleifer and Kocur (22).

The guanine-plus-cytosine content of the deoxyribonucleic acid (DNA) of strain CBCC 1462 was determined by the method of Meyer and Schleifer (20). The DNA-DNA hybridization technique with nitrocellulose filters was used to determine genetic relatedness. Nitrocellulose filters (Sartorius, diameter, $50 \mathrm{~mm}$; pore size, $0.2 \mu \mathrm{m}$ ) were loaded by the procedure of Gillespie and Spiegelmann (12) with unlabeled, alkali-denatured DNA. Small disks (diameter, $5 \mathrm{~mm}$ ) were punched from the larger filters and were preincubated by the procedure of Denhardt $(7) .\left[6-{ }^{3} \mathrm{H}\right]$ thymidinelabeled DNA was sheared with a French press at $20,000 \mathrm{lb} / \mathrm{in}^{2}$ and dissolved in reassociation buffer $(0.6$ $\mathrm{M} \mathrm{NaCl}-0.06 \mathrm{M}$ trinatrium citrate $[\mathrm{pH} 7.0]$ containing $20 \%$ formamide) to a final concentration of $0.4 \mu \mathrm{g} / 200$ $\mu 1$ and heat denatured. Two hundred microliters of labeled DNA was added to the preincubated filters, and the reaction was allowed to proceed for $30 \mathrm{~h}$ at $60^{\circ} \mathrm{C}$. Between 50 and $60 \%$ of the added labeled DNA bound to the filter in the homologous reaction. This was considered to represent $100 \%$ homology, and all heterologous reactions were normalized accordingly. DNA homology values, therefore, refer to the relative binding capacity expressed as the ratio (given as a percentage) of the amount of labeled DNA which reassociated with filter-bound DNA of various reference strains (heterologous reaction) to the amount of labeled DNA which reassociated with the filterbound DNA from the same strain from which the labeled DNA was obtained (homologous reaction). Allowing DNA-DNA hybridization to proceed at $25^{\circ} \mathrm{C}$ below the melting point of the DNA in a particular buffer is considered to represent the optimal reassociation condition. Higher reaction specificity can be obtained by decreasing the temperature span between the DNA melting point and the temperature of reassociation so that the formation of stable hybrids between the labeled DNA and the filter-bound DNA is restricted to more closely matching base sequences. By employing formamide and using an incubation temperature of $60^{\circ} \mathrm{C}$, we achieved restrictive reassociation conditions about $18^{\circ} \mathrm{C}$ below the melting point of the DNA. A detailed description of the DNA hybridization procedure used in this study is given by Meyer and Schleifer (Arch. Microbiol., in press).

\section{RESULTS}

The strains under investigation clustered into two groups. One hundred and thirty-two strains, which were very similar to strain NCTC 10350 , one of the strains originally isolated and named $M$. hyicus by Sompolinsky (26), were placed in group A (Table 1). Thirty-six other strains isolated from cows with subclinical mastitis and from the intact skin of pigs (Table 1) were placed in group B. Their characters were similar to those of strain NCTC 10530 originally isolated by Baird-Parker (2) from the skin of a pig and subsequently placed in Staphylococcus epidermidis biotype 2 (4).

Characterization of group A strains. Cells of group A strains were nonsporeforming, nonmotile, gram-positive cocci, 0.6 to $1.3 \mu \mathrm{m}$ in diameter (predominantly 0.8 to $1.0 \mu \mathrm{m}$ ), arranged in pairs, tetrads, and small groups; occasionally they occurred singly.

Colonies were circular, entire, 3 to $5 \mathrm{~mm}$ in diameter, low convex, and opaque with a glistening surface. Pigments were not produced. In liquid media, uniform turbidity with a deposit was seen. The strains did not grow or grew weakly in nutrient broth (Oxoid) at $45^{\circ} \mathrm{C}$ and showed delayed growth in static nutrient broth cultures incubated at $22^{\circ} \mathrm{C}$.

Tests in which all strains reacted uniformly positively or negatively are listed in Table 2, which contains results obtained with strains belonging to both groups described in this paper. All group A strains were also positive in one 
TABLE 1. Strains investigated

\begin{tabular}{|c|c|c|c|c|}
\hline \multirow{2}{*}{ Laboratory no. } & \multicolumn{3}{|c|}{ Origins } & \multirow{2}{*}{$\begin{array}{l}\text { Refer- } \\
\text { ence(s) }\end{array}$} \\
\hline & Animal species & Country & Source $^{a}$ & \\
\hline \multicolumn{5}{|l|}{ Group A strains } \\
\hline $\begin{array}{l}\text { VA302, VA303, VA305-VA308, VA310, VA317, VA319, } \\
\text { VA323, VA325-VA330, VA332, VA333, VA341-VA344, } \\
\text { VA346-VA351 }\end{array}$ & Swine (lesions) & Belgium & 1 & 8,9 \\
\hline $\begin{array}{l}\text { VA353-VA356, VA358-VA362, VA501-VA505, } \\
\text { VA507-VA511, VA513-VA539, VA541-VA551 }\end{array}$ & Swine (healthy) & Belgium & 1 & 8,9 \\
\hline SH1, SH3-SH9 & Swine (lesions) & Czechoslovakia & 2 & \\
\hline $2869 c / 70,5170 / 73$ & Swine (lesions) & Germany & 3 & 1 \\
\hline H310, H343 & Swine (lesions) & England & 4 & 15 \\
\hline NCTC $10350=$ CCM 2368 & Swine (lesions) & Denmark & 5 & 26 \\
\hline A4, A252, A273, A313, A332, A355, A387, 201-1 & Cows (lesions) & United States & 6 & 5 \\
\hline $\begin{array}{l}\text { VII26, VII27, VII28, VII52, VII53, VII63, VII76, VII96, } \\
\text { VII99, VII100, VII108, VII111 }\end{array}$ & Poultry (healthy) & Belgium & 1 & 9 \\
\hline $\mathrm{K} 13, \mathrm{~K} 19, \mathrm{~K} 20, \mathrm{~K} 24, \mathrm{~K} 46, \mathrm{~K} 57, \mathrm{~K} 127, \mathrm{~K} 129, \mathrm{~K} 130$ & Poultry (healthy) & Rwanda & 7 & 9 \\
\hline J12, J13, J14, J16, J17 & Poultry (healthy) & Japan & 8 & 9,21 \\
\hline \multicolumn{5}{|l|}{ Group B strains } \\
\hline CBCC $1462=$ NCTC 10530 & & England & 9 & 2 \\
\hline $\begin{array}{l}\text { VA102, VA103, VA104, VA110, VA111, VA401, VA404, } \\
\text { VA406, VA608, VA647, VA650, VA652, VA654, VA656, } \\
\text { VA666, VA669, VA672 }\end{array}$ & Swine (healthy) & Belgium & 1 & \\
\hline $\begin{array}{l}\text { Bo4, Bo14, Bo18, Bo43, Bo49, Bo52, Bo59, Bo64, Bo66, } \\
\text { Bo81, Bo83, Bo90, Bo91, Bo93, Bo98, Bo129, Bo153, } \\
\text { Bo157 }\end{array}$ & Cows (lesions) & Belgium & 1 & \\
\hline
\end{tabular}

${ }^{a}$ 1, L. A. Devriese, Gent, Belgium; 2, V. Hájek, Olomouc, C.B.S.R.; 3, G. Amtsberg, Hannover, B.R.D.; 4, D. Hunter, Leeds, England; 5, National Collection of Type Cultures, London, England and Czechoslovak Collection of Microorganisms, Purkyne University, Brno, C.S.S.R.; 6, R. W. Brown, Ames, Iowa; 7, L. Van Damme, Butare, Rwanda; 8, G. Sato, Sapporo, Japan; 9, A. C. Baird-Parker, Sharnbrook, Bedford, England.

TABLE 2. Characteristics of S. hyicus: tests for which all strains reacted uniformly

\begin{tabular}{|c|c|}
\hline Positive reaction & Negative reaction \\
\hline $\begin{array}{l}\text { Anaerobic growth } \\
\text { Benzidine test } \\
\text { Catalase test } \\
\text { Clearing on milk agar } \\
\text { Gelatinase production } \\
\text { Nitrate reduction beyond nitrite } \\
\text { Phosphatase production } \\
\text { Acid from: } \\
\text { Sucrose } \\
\text { Mannose }\end{array}$ & $\begin{array}{l}\text { Motility } \\
\text { Growth on medium with } 15 \% \mathrm{NaCl} \\
\text { Growth on Simmons citrate agar } \\
\text { Oxidase production } \\
\text { Clumping-factor production } \\
\text { Hemolysin } \alpha, \beta \text {, or } \delta \\
\text { Hydrogen sulfide production } \\
\text { Indole production } \\
\text { Phenylalanine-deaminase production } \\
\text { Tellurite reduction } \\
\text { Acetylmethylcarbinol production } \\
\text { Hydrolysis of esculin } \\
\text { Acid from: } \\
\text { Adonitol } \\
\text { Amygdaline } \\
\text { L-(+)-Arabinose } \\
\text { Arabitol } \\
\text { Cellobiose } \\
\text { Dulcitol } \\
\text { L-(-)-Fucose } \\
\beta \text {-Gentiobiose } \\
\text { Lyxose } \\
\text { Melibiose } \\
\text { Melezitose } \\
\text { Raffinose } \\
\text { L-(+)-Rhamnose } \\
\text { Salicin } \\
\text { Sorbitol } \\
\text { Sorbose } \\
\text { Tagatose } \\
\text { Xylitol } \\
\text { Xylose }\end{array}$ \\
\hline
\end{tabular}

${ }^{a}$ Tested in thioglycolate broth as described by Evans and Kloos (11). 
further test: the heat-stable deoxyribonuclease reaction. In some tests, a great majority of the group A strains reacted uniformly, but a few exceptions were noted (Table 3). In a few other tests, the strains reacted differently depending upon the nature and geographic origin of the host species (Table 4).

Thirty-eight selected strains were found to produce predominantly L-lactic acid from glucose under anaerobic conditions. The $\mathrm{pH}$ in peptone-yeast extract-glucose broth (10) was lowered from 6.8-7.1 to 4.8-5.3 after 5 days of anaerobic incubation.

The strains were uniformly resistant to lysozyme (MIC, $>800 \mu \mathrm{g} / \mathrm{ml}$ ). They were susceptible to novobiocin (MIC, 0.05 to $0.1 \mu \mathrm{g} / \mathrm{ml}$; with one exception: strain VA346), lysostaphin (MIC, 12.5 to $25 \mu \mathrm{g} / \mathrm{ml}$ ), cloxacillin (MIC, 0.1 to $0.2 \mu \mathrm{g} / \mathrm{ml}$ ), cephaloridine (MIC, 0.025 to $0.1 \mu \mathrm{g} / \mathrm{ml}$ ), bacitracin (MIC, 0.01 to $0.8 \mathrm{U} / \mathrm{ml}$ ), neomycin (MIC, 0.1 to $0.4 \mu \mathrm{g} / \mathrm{ml}$; with two exceptions), rifamycin (MIC, 0.006 to $0.025 \mu \mathrm{g} / \mathrm{ml}$ ), furazolidone (MIC, 0.8 to $1.6 \mu \mathrm{g} / \mathrm{ml}$ ), trimethoprim (MIC, 0.8 to 1.6 $\mu \mathrm{g} / \mathrm{ml}$ ), sulfamethoxazole (MIC, 25 to $50 \mu \mathrm{g} / \mathrm{ml}$ ), and penicillin G (MIC, 0.025 to $0.05 \mu \mathrm{g} / \mathrm{ml}$ ). Some strains, however, possessed penicillinase activity, and their penicillin G MIC levels were not regularly reproducible. Levels of susceptibility to erythromycin, lincomycin, streptomycin, sulfamethoxazole, tetracycline hydrochloride, and chloramphenicol were biomodally distributed. This was probably caused by resistance determinants. The polymyxin B sulfate MICs were 100 to $200 \mu \mathrm{g} / \mathrm{ml}$.

None of the strains was susceptible to phages of the human and bovine $S$. aureus typing sets.

TABLE 3. Characteristics of $S$. hyicus subsp. hyicus (group A): tests in which there were strain differences independent of the origin of the strains

\begin{tabular}{lccc}
\hline \multicolumn{1}{c}{ Characteristic } & $\begin{array}{c}\text { No. of strains } \\
\text { positive/total } \\
\text { no. of strains }\end{array}$ & $\begin{array}{c}\text { Reaction of } \\
\text { type strain } \\
\text { (NCTC 1035) }\end{array}$ & \multicolumn{1}{c}{$\begin{array}{c}\text { Reference numbers of strains } \\
\text { that gave the less common result }\end{array}$} \\
\hline Hydrolysis of hippurate $\ldots \ldots \ldots \ldots$ & $130 / 132$ & + & VA341, VA348 \\
Hydrolysis of arginine $\ldots \ldots \ldots \ldots \ldots$ & $131 / 132$ & + & A4 \\
Hydrolysis of Tweens $\ldots \ldots \ldots \ldots \ldots$ & $130 / 132$ & + & VA323, K130 \\
Production of hyaluronidase $\ldots \ldots$ & $128 / 132$ & + & VII26, VII27, VII76, VA548 \\
Acid from ribose $\ldots \ldots \ldots \ldots \ldots \ldots$ & $131 / 132$ & + & A4 \\
Acid from glycerol $\ldots \ldots \ldots \ldots \ldots \ldots$ & $130 / 132$ & - & NCTC 10530, VA350 \\
Acid from fructose $\ldots \ldots \ldots \ldots \ldots \ldots$ & $130 / 132$ & + & A4, VII99 \\
\hline
\end{tabular}

TABLE 4. Characters of S. hyicus subsp. hyicus (group A) which vary according to the nature and geographic localization of the host species

\begin{tabular}{|c|c|c|c|c|c|}
\hline \multirow{3}{*}{ Characteristic } & \multicolumn{5}{|c|}{ No. positive strains/no. strains tested } \\
\hline & \multirow{2}{*}{$\begin{array}{c}\text { Pigs } \\
\text { Europe }\end{array}$} & \multicolumn{3}{|c|}{ Poultry } & \multirow{2}{*}{$\frac{\text { Cows }}{\text { America }}$} \\
\hline & & Europe & Africa & Japan & \\
\hline \multicolumn{6}{|l|}{ Tube coagulase (rabbit plasma) } \\
\hline Clotting after $1 \mathrm{~h}$ & $3 / 98$ & $0 / 12$ & $0 / 9$ & $1 / 5$ & $0 / 8$ \\
\hline $3 \mathrm{~h}$ & $3 / 98$ & $0 / 12$ & $4 / 9$ & $4 / 5$ & $0 / 8$ \\
\hline $24 \mathrm{~h}$ & $12 / 98^{a}$ & $2 / 12^{a}$ & $5 / 9^{a}$ & $5 / 5$ & $8 / 8$ \\
\hline Trehalose reaction & $97 / 98^{b}$ & $9 / 12^{b}$ & $9 / 9$ & $5 / 5$ & $2 / 8^{b}$ \\
\hline Lactose/galactose reactions & $97 / 98^{c}$ & $8 / 12^{c}$ & $4 / 9^{c}$ & $5 / 5$ & $8 / 8$ \\
\hline Urease & $97 / 98^{d}$ & $12 / 12$ & $3 / 9^{d}$ & $5 / 5$ & $8 / 8$ \\
\hline Fibrinolysin production & $54 / 98^{e}$ & $0 / 12$ & $0 / 9$ & $0 / 5$ & $0 / 8$ \\
\hline Polysaccharide $C$ in cell wall & $25 / 95^{f}$ & $7 / 12^{8}$ & $8 / 8$ & $4 / 4$ & $6 / 8^{g}$ \\
\hline
\end{tabular}

${ }^{a}$ The following strains were positive after $24 \mathrm{~h}$ in rabbit plasma: K13, K19, K20, K127, K129, VII28, VII111, H310, VA305, VA306, VA307, VA350, VA359, VA510, VA521, VA528, VA541, VA542, VA547.

${ }^{b}$ The following strains were negative: VA519, A252, A273, A313, A332, A355, A387, VII28, VII108, VII111.

' The following were negative: K13, K19, K20, K127, K129, VII52, VII96, VII99, VII101, VA354.

${ }^{d}$ The following were negative: K13, K19, K20, K57, K127, K129, NCTC 10350.

e The following strains were positive: NCTC 10350, H310, H343, SH1, SH3-SH9, VA306, VA307, VA310, VA326-VA329, VA333, 2869c/70, 5170/73, VA341, VA344, VA348, VA349, VA351, VA353, VA354, VA356, VA361, VA501, VA502, VA599-VA511, VA514, VA515, VA518-VA520, VA522-VA525, VA529, VA530, VA532, VA533, VA535, VA538, VA541, VA542, VA551.

${ }^{f}$ The following strains were positive: VA302, VA310, VA323, VA327, VA328, VA332, VA333, VA341, VA342, VA348, VA350, VA351, VA354, VA355, VA358, VA530, VA535, VA536, VA537, VA539, VA546, VA547, VA549, VA551, SH4.

8 The following strains were negative: VII52, VII63, VII96, VII99, VII100, A4, 201-1. 
All of the strains except five (2869c, H310, H343, K24, J14) were examined serologically with respect to their type of cell wall teichoic acid. All produced a precipitation line showing a reaction of identity with the VA308 reference line. The teichoic acid responsible for this line, provisionally designated Al (9), has recently been identified as an $\alpha-N$-acetylglucosaminyl glycerol teichoic acid (Osland, Grov, and Oeding, submitted for publication). Fifty strains contained $\beta$ - $N$-acetylglucosaminyl glycerol teichoic acid (polysaccharide $C$ ) as well (Table 4). Strains VA310, VA333, A4, J12, and VII96 lacked Lserine in their cell wall peptidoglycan. The other strains examined (SH1, SH3-SH9, VA302, VA303, VA305-VA308, VA317, VA319, VA323, VA325-VA330, VA332, VA355-VA357, VA501VA503, 2869c/70, 5170/73, NCTC 10350) contained only trace amounts of serine $(0.1$ to 0.3 mol of serine per mol of glutamic acid).

Characterization of group B strains. The cell morphology and characteristics of the group B strains were similar to those of the group A strains, except that the group B strains produced a yellow, orange, or creamy pigment.

In addition to the characteristics listed in Table 2, the following reactions were uniformly negative with the group B strains: tube coagulase with rabbit plasma, precipitation on media containing Tween 80 or Tween 85 , and production of hyaluronidase and fibrinolysin. In the deoxyribonuclease plate tests, zones of clearing, after addition of $\mathrm{HCl}$, were seen which were always smaller than the zones produced by group A strains. In the heat-stable-deoxyribonuclease test, most strains produced small reaction zones which were difficult to read. All group B strains produced zones of clearing on tributyrin agar which were narrower than the zones seen with group A strains.

All group B strains were positive in the hippurate, arginine dihydrolase, and urease tests. All produced acid from glycerol, ribose, fructose, trehalose, lactose, and galactose. Twenty-one strains $(58 \%)$ were mannitol positive, $18(50 \%)$ produced acid from maltose, and $16(44 \%)$ produced acid from turanose. The reactions with mannitol, maltose, and turanose were only weakly positive and were most readily demonstrable in phenol red broth. When the fluid medium of Evans et al. (10) was used with mannitol replacing glucose, the $\mathrm{pH}$ was lowered from 6.8 to 4.7-6.5. In similar tests with maltose, $\mathrm{pH}$ values ranging from 5.1 to 6.7 were obtained. Other positive results are listed in Table 2.

The susceptibility levels of the group B strains to antimicrobial agents were similar to those described for group A strains, except that slightly lower MICs were obtained with tetracycline hydrochloride and trimethoprim. The trimethoprim MICs were 0.1 to $0.4 \mu \mathrm{g} / \mathrm{ml}$ with group $B$ and 0.8 to $1.6 \mu \mathrm{g} / \mathrm{ml}$ with group $A$ strains. The tetracycline hydrochloride susceptibility levels were 0.1 to $0.2 \mu \mathrm{g} / \mathrm{ml}$ for group B and 0.4 to $0.8 \mu \mathrm{g} / \mathrm{ml}$ for group A strains. The tetracycline-resistant group B strains had MICs of 6.3 to $12.5 \mu \mathrm{g} / \mathrm{ml}$, whereas the tetracyclineresistant group A strains were inhibited at 25 to $100 \mu \mathrm{g} / \mathrm{ml}$.

The strains were not lysed by the phages used for typing human and bovine $S$. aureus strains.

All except two of the strains (Bo64, Bo83) were examined serologically with respect to their type of cell wall teichoic acid. All except one (VA404) produced the A1 precipitation line. Seventeen strains (CBCC1462, VA103, VA104, VA110, VA11, VA401, VA608, VA647, VA650, VA656, VA669, Bo14, Bo18, Bo81, Bo93, Bo129, Bo153) contained $\beta$ - $N$-acetylglucosaminyl glycerol teichoic acid as well. Strain VA404 contained exclusively $\beta$ - $N$-acetylglucosaminyl glycerol teichoic acid. The strains VA406 and Bo18 lacked L-serine in their cell wall peptidoglycan. The other strains studied (CBCC 1462, VA650, Bo4, Bo43, and Bo59) contained only trace amounts of serine $(0.1$ to $0.3 \mathrm{~mol} / \mathrm{mol}$ of glutamic acid). Fifteen selected strains produced predominantly $\mathbf{L}$-lactic acid from glucose under anaerobic growth conditions. The guanine-plus-cytosine content of the DNA of strain NCTC 10530 was $33.9 \mathrm{~mol} \%$.

\section{DISCUSSION}

The two groups of bacteria examined in this study differ from Micrococcus species in the following characters: they have a low guanineplus-cytosine content in their DNA; they have a teichoic acid in their cell walls and a peptidoglycan different from that of micrococci; they are susceptible to lysostaphin; they have a lowconvex colony profile; they grow anaerobically in thioglycolate medium; and they produce acid from glycerol.

One of the group A strains, viz. NCTC 10350 (= Sompolinsky strain 1), is one of the strains on which Sompolinsky based his original description of Micrococcus hyicus (26). This strain possesses the characters given in the original description of the species, and it is here designated the type strain of $M$. hyicus. Because the type strain of $M$. hyicus, together with the other group A and B strains, is here regarded as belonging to the genus Staphylococcus as a distinct species, the name of this species is Staphylococ. cus hyicus (Sompolinsky) comb. nov.

A description of this species follows: Non- 
sporeforming, gram-positive cocci, predominantly 0.8 to $1.0 \mu \mathrm{m}$ in diameter, arranged in pairs, tetrads, and small groups; occasionally cells occur singly. Colonies are circular, entire, 3 to $5 \mathrm{~mm}$ in diameter, low convex, and opaque with a glistening surface. Broth cultures are uniformly turbid with a deposit. Physiological characteristics common to all of the known strains of this species are listed in Table 2. Nearly all of the strains hydrolyze hippurate and arginine and produce acid from ribose, glycerol, and fructose. The strains produce predominantly L-lactic acid from glucose under anaerobic conditions. They are resistant to lysozyme and susceptible to lysostaphin and the commonly used antibiotics active against gram-positive bacteria. Their cell walls contain $\alpha-N$-acetylglucosaminyl glycerol teichoic acid and lack L-serine or contain only trace amounts of this substance. The strains are not susceptible to the phages used for typing $S$. aureus strains from human and bovine sources.

Type strain: Strain D. Sompolinsky 1 (= ATCC $11249=$ CCM $2368=$ NCTC 10350); from the skin of a pig affected with exudative epidermitis in Seeland, Denmark.

A DNA-DNA hybridization study of S. hyicus strains which differ in several characteristics from each other (Table 4; see Table 6) revealed that the strains could be subdivided into at least two groups, each composed of strains with homology values above $90 \%$ (strain VA 306 with NCTC 10350 and strain CBCC 1462 with Bo4 in Table 5). However, when members from these different groups were compared, lower hybridization rates ranging from 30 to $50 \%$ were de- tected. Such low homology values indicate that these two groups are related to each other at a subspecies level. Group A and group B strains differ from each other in several easily recognizable characters (Table 6). Therefore, subspecies status is proposed here for these two groups. Group A contains the type strain of the species, and therefore the name of this subspecies is $S$. hyicus subsp. hyicus. For the other subspecies (group B), the name $S$. hyicus subsp. chromogenes subsp. nov. is proposed (chro.mó.ge.nes. Gr. n. chroma color; Gr. v. gennaio to produce; M.L. adj. chromogenes producing color). The characteristics which differentiate $S$. hyicus subsp. hyicus from $S$. hyicus subsp. chromogenes are given in Table 6.

The following characteristics are considered essential for membership in $S$. hyicus subsp. hyicus: presence of a heat-stable nuclease and absence of clumping-factor activity and hemolysins; presence of $\alpha-N$-acetylglucosaminyl glycerol teichoic acid in the cell wall; ability to produce acid from mannose and sucrose but not from maltose, mannitol, xylose, arabinose, or cellobiose; reduction of nitrates; and absence of pigment production. For membership in $S$. hyicus subsp. chromogenes, the following features are essential: weak or absent heat-stable nuclease; absence of clumping-factor activity and hemolysins; presence of $\alpha-N$-acetylglucosaminyl glycerol teichoic acid in the cell wall; ability to reduce nitrates and to produce acid from mannose, trehalose, and sucrose; and absence of activity on xylose, arabinose, and cellobiose. These characteristics, together with the diagnostic reactions which distinguish the two $S$. hyicus sub-

TABLE 5. DNA-DNA homology values of $S$. hyicus strains and other strains

\begin{tabular}{|c|c|c|c|c|c|c|c|c|c|}
\hline \multirow[b]{2}{*}{$\mathrm{DNA}_{8}{ }^{a}$ from: } & \multicolumn{9}{|c|}{$\mathrm{DNA}_{\mathrm{f}}{ }^{b}$ from: } \\
\hline & A4 & $\begin{array}{l}\text { VA } \\
306\end{array}$ & $\begin{array}{c}\text { NCTC } \\
10350\end{array}$ & $\begin{array}{c}\text { CBCC } \\
1462\end{array}$ & Bo4 & H11 & $\begin{array}{c}\text { ATCC } \\
12600\end{array}$ & $\begin{array}{c}\text { ATCC } \\
14990\end{array}$ & AM63 \\
\hline \multicolumn{10}{|c|}{ Staphylococcus hyicus subsp. hyicus } \\
\hline A4 & 100 & 48 & 49 & 35 & 30 & 17 & 15 & 14 & 8 \\
\hline VA306 & 48 & 100 & 93 & 32 & 32 & 10 & 10 & 10 & 2 \\
\hline NCTC 10350 & 52 & 95 & 100 & 45 & 40 & 19 & 14 & 17 & 3 \\
\hline \multicolumn{10}{|l|}{ S. hyicus subsp. chromogenes } \\
\hline CBCC 1462 & 47 & 55 & 52 & 100 & 95 & 17 & 19 & 19 & 3 \\
\hline Bo4 & 33 & 40 & 36 & 92 & 100 & 17 & 9 & 13 & 3 \\
\hline \multicolumn{10}{|l|}{ S. intermedius } \\
\hline H11 & 10 & 11 & 12 & 11 & 10 & 100 & 7 & 7 & 2 \\
\hline \multicolumn{10}{|l|}{ S. aureus } \\
\hline ATCC 12600 & 12 & 11 & 10 & 10 & 11 & 10 & 100 & 16 & 6 \\
\hline \multicolumn{10}{|l|}{ S. epidermidis } \\
\hline ATCC 14990 & 15 & 10 & 14 & 19 & 9 & 12 & 16 & 100 & 6 \\
\hline \multicolumn{10}{|l|}{ Lactobacillus acidophilus } \\
\hline AM63 & 9 & 9 & 6 & 7 & 8 & 8 & 8 & 8 & 100 \\
\hline
\end{tabular}

${ }^{a}$ DNA $_{\mathrm{s}}$, Labeled DNA in solution.

${ }^{b}$ DNA $_{f}$, DNA immobilized on filter. 
species from the most phenotypically related other Staphylococcus species (Table 7), can be used for the identification of $S$. hyicus. None of the other presently known Staphylococcus species $(13,16,17,23)$ possess the combination of characteristics described here for $S$. hyicus.

S. hyicus subsp. hyicus occurs commonly on the skin of poultry and pigs $(8,21)$ and is more rarely isolated from cows with mastitis (5). Bovine and poultry strains do not cause a visible effect when inoculated in colostrum-deprived pigs, whereas porcine strains are highly pathogenic (9). The poultry strains are probably not pathogenic for chickens (21).

$S$. hyicus subsp. chromogenes can be isolated from the skin of pigs and mastitic milk of cows, but its importance is unknown.

Description of the type strain of S. hyicus subsp. hyicus. (Strain D. Sompolinsky $1=$ ATCC 11249 = CCM 2368 = NCTC 10350).

Cells are gram-positive spheres, 0.6 to $1.3 \mu \mathrm{m}$ in diameter, occurring in pairs, tetrads, and ir-

TABLE 6. Characters useful in differentiating the subspecies of S. hyicus ${ }^{a}$

\begin{tabular}{|c|c|c|}
\hline Character & $\begin{array}{c}\text { S. hyicus } \\
\text { subsp. } \\
\text { hyicus } \\
\text { (group A) }\end{array}$ & $\begin{array}{c}\text { S. hyicus } \\
\text { subep. } \\
\text { chromogenes } \\
\text { (group B) }\end{array}$ \\
\hline Heat-stable nuclease . . . . . . & + & Slight or - \\
\hline Hyaluronidase production . . & + & - \\
\hline Pigment production . . . . . . & - & + \\
\hline Tween 80 and 85 splitting .. & + & - \\
\hline Acid from mannitol $\ldots . .$. & - & D \\
\hline Acid from maltose $\ldots \ldots \ldots$ & - & D \\
\hline Acid from turanose $\ldots \ldots \ldots$ & $\bar{z}$ & D \\
\hline $\begin{array}{c}\text { Coagulase (rabbit plasma) } \\
\text { production } \ldots \ldots \ldots \ldots \ldots\end{array}$ & $\mathbf{D}$ & - \\
\hline Production of fibrinolysin .. & $\mathrm{D}$ & - \\
\hline
\end{tabular}

${ }^{6}$ Reactions:,$+>90 \%$ positive;,$->90 \%$ negative; $D, 11$ to $89 \%$ positive. regular groups; occasionally they occur singly. Endospores are not produced. Nonmotile.

Agar colonies: Circular, entire, 3 to $5 \mathrm{~mm}$ in diameter, low convex, opaque with a glistening surface. No pigment.

Broth cultures: Uniformly turbid with a deposit.

The biochemical characters of this strain are listed in Tables 2 and 8.

Antibiotic susceptibilities: Resistant to lysozyme. Susceptible to novobiocin, lysostaphin, penicillins, bacitracin, neomycin, streptomycin, rifamycin, furazolidone, erythromycin, lincomycin, tetracycline, chloramphenicol, sulfamethoxazole, and trimethoprim.

Not susceptible to phages of the international $S$. aureus typing set or to those used for typing bovine $S$. aureus strains.

Cell wall composition: Peptidoglycan is of the L-Lys-Gly - $_{5-6}$ type (22); trace amounts of glycan can be replaced by L-serine. Teichoic acid: $\alpha-N$ acetylglucosaminyl glycerol teichoic acid.

Guanine-plus-cytosine content of the DNA: $32.9 \mathrm{~mol} \%$ (18).

Pathogenic to pigs.

Description of the type strain of S. hyicus subsp. chromogenes. The strain originally isolated in 1963 by Baird-Parker from the skin of a pig and designated CBCC 1462 (= NCTC 10530 ) is the type strain of $S$. hyicus subsp. chromogenes. The characteristics of this strain are as follows.

Cells: Gram-positive spheres, 0.7 to $1.3 \mu \mathrm{m}$ in diameter, occurring in pairs, tetrads, and irregular groups; occasionally they occur singly. Nonsporeforming. Nonmotile.

Agar colonies: Circular, entire, 3 to $5 \mathrm{~mm}$ in diameter, low convex, and opaque with a glistening surface. Orange pigment.

TABLE 7. Diagnostic features useful in distinguishing between the S. hyicus subspecies and related Staphylococcus species ${ }^{a}$

\begin{tabular}{|c|c|c|c|c|c|}
\hline Character & $\begin{array}{l}\text { S. } \\
\text { hyicus } \\
\text { subsp. } \\
\text { hyicus }\end{array}$ & $\begin{array}{c}\text { S. hyicus } \\
\text { subsp. } \\
\text { chromogenes }\end{array}$ & $\begin{array}{c}\text { S. } \\
\text { inter- } \\
\text { medius }\end{array}$ & $\begin{array}{c}\text { S. } \\
\text { aureus }\end{array}$ & S. simulans \\
\hline Coagulase (rabbit plasma) production . . . . . & $\mathbf{D}$ & - & + & + & - \\
\hline Heat-stable nuclease production .... & + & Slight or - & + & + & - \\
\hline Clumping-factor production ..... & - & - & $\mathbf{D}$ & + & $-b$ \\
\hline Pigment production $\ldots \ldots \ldots \ldots$ & - & + & - & + & Slight or - \\
\hline Hemolysins $\alpha$ and/or $\beta$ and/or $\delta$. & - & - & $\mathbf{D}$ & + & - \\
\hline Hyaluronidase production ....... & + & - & - & + & $-b$ \\
\hline Hydrolysis of Tween $80 \ldots \ldots$ & + & - & + & $\mathbf{D}$ & $+^{b}$ \\
\hline Acid from mannitol .... & - & $\mathbf{D}$ & + & + & + \\
\hline Phosphatase production & + & + & + & + & Weak or - \\
\hline
\end{tabular}

'Based on references 13, 14, and 16. Reaction:,$+>90 \%$ of strains positive;,$->90 \%$ of strains negative; $D, 11$ to $89 \%$ positive.

${ }^{b}$ Based on unpublished results of tests with 2 strains only (CCM 2705 and CCM 2724). 
TABLE 8. Biochemical characteristics of the type strains of $S$. hyicus subsp. hyicus and $S$. hyicus subsp. chromogenes

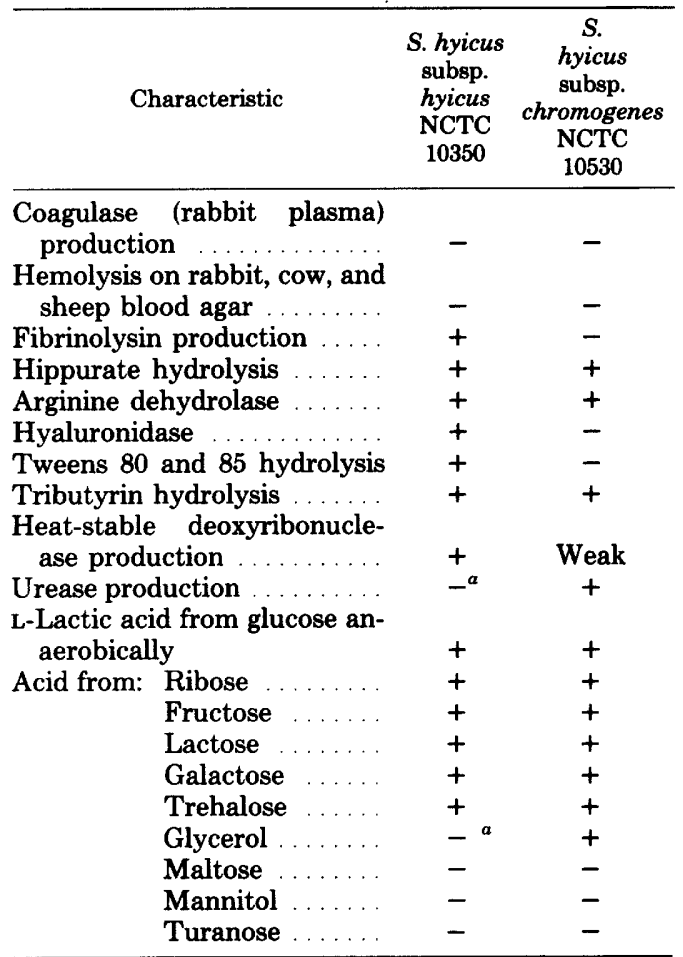

${ }^{a}$ Atypical character.

Broth cultures: Uniformly turbid with a deposit.

The biochemical characteristics of this strain are listed in Tables 2 and 8.

Antibiotic susceptibilities: Resistant to lysozyme. Susceptible to novobiocin, lysostaphin, penicillins, bacitracin, neomycin, streptomycin, rifamycin, furazolidone, erythromycin, lincomycin, tetracycline, chloramphenicol, sulfamethoxazole, and trimethoprim.

Not susceptible to the phages of the international $S$. aureus typing set or to those used for typing bovine $S$. aureus strains.

Cell wall composition: Peptidoglycan is of the L-Lys-Gly ${ }_{5-6}$ type; trace amounts of glycan can be replaced by L-serine. Teichoic acid: $\alpha-N$-acetylglucosaminyl glycerol teichoic acid and $\beta-N$. acetylglucosaminyl glycerol teichoic acid.

$\mathrm{G}+\mathrm{C}$ content of the DNA: $33.9 \mathrm{~mol} \%$.

When S. hyicus strains were compared with reference strains of $S$. aureus, $S$. intermedius, or coagulase-negative organisms such as $S$. epidermidis, low DNA homology values (below 17\%) were found (Table 5). Less than 8\% homology resulted when $S$. hyicus was compared with a phenotypically unrelated reference organism ( $L$. acidophilus).

The DNA of group A strain $\mathrm{A}_{4}$ is 30 to $52 \%$ homologous with the DNAs from other S. hyicus strains, an indication for another subspecies relationship. $A_{4}$ and the other strains isolated from cows in the United States all originated from one herd. Some of their phenotypic characters differed from those of the other S. hyicus subsp. hyicus strains, but none of the tests used in this study could clearly differentiate these strains (Table 4). Other S. hyicus strains from other animal hosts and other geographic regions also differed in several characteristics from each other (Table 4). It remains to be seen whether these host-adapted strains belong to different "biotypes" or formae speciales, analogous to the biotypes described in $S$. aureus (14) and $S$. intermedius $(13,14)$, or to different subspecies. Therefore, it is proposed that strain $A_{4}$ and similar strains from other origins should provisionally be placed in S. hyicus subsp. hyicus.

\section{REPRINT REQUESTS}

Address reprint requests to: L. A. Devriese, Faculty of Veterinary Medicine, Casinoplein 24, B-9000 Gent, Belgium.

\section{LTERATURE CITED}

1. Amtsberg, G., W. Bollwahn, S. Hazem, B. Jordan, and U. Schmidt. 1973. Bakteriologische, serologische und tierexperimentelle Untersuchungen zür ätiologischen Bedeutung von Staphylococcus hyicus beim nässendem Ekzem des Schweines. Dtsch. Tieraerztl. Wochenschr. 80:493-499, 521-523.

2. Baird-Parker, A. C. 1962. The occurrence and enumeration, according to a new classification, of micrococci and staphylococci in bacon and on human and pig skin. J. Appl. Bacteriol. 25:352-361.

3. Baird-Parker, A. C. 1963. The classification of staphylococci from world-wide sources. J. Gen. Microbiol. 38:363-387.

4. Baird-Parker, A. C. 1974. Genus II. Staphylococcus Rosenbach 1884, 18 nom. cons. Opin. 17 Jud. Comm. 1958, p. 483-489. In R. E. Buchanan and N. E. Gibbons (ed.), Bergey's manual of determinative bacteriology, 8 th ed. The Williams \& Wilkins Co., Baltimore.

5. Brown, R. W., O. Sandvik, R. K. Sherer, and D. L. Rose. 1967. Differentiation of strains of Staphylococcus epidermidis isolated from bovine udders. J. Gen. Microbiol. 47:273-287.

6. Davis, G. H. G., and B. Hoyling. 1973. Use of a rapid acetoin test in the identification of staphylococci and micrococci. Int. J. Syst. Bacteriol. 23:281-282.

7. Denhardt, D. T. 1966. A membrane filter technique for the detection of complementary DNA. Biochem. Biophys. Res. Commun. 23:641-646.

8. Devriese, L. A. 1977. Isolation and identification of Staphylococcus hyicus. Am. J. Vet. Res. 38:787-792.

9. Devriese, L. A., and P. Oeding. 1975. Coagulase and heat-resistant nuclease producing Staphylococcus epidermidis strains from pigs. J. Appl. Bacteriol. 39:197-207.

10. Evans, J. B., W. L. Bradford, Jr., and C. F. Niven, Jr. 1955. Comments concerning the taxonomy of the genera Micrococcus and Staphylococcus. Int. Bull. Bacteriol. Nom. Taxon. 5:61-66. 
11. Evans, J. B., and W. E. Kloos. 1972. Use of shake cultures in a semisolid thioglycolate medium for differentiating staphylococci from micrococci. Appl. Microbiol. 23:326-331.

12. Gillespie, D., and S. Spiegelman. 1965. A quantitative assay for DNA-DNA hybrids with DNA immobilized on a membrane. J. Mol. Biol. 12:829-842.

13. Hájek, V. 1976. Staphylococcus intermedius, a new species isolated from animals. Int. J. Syst. Bacteriol. 26:401-408.

14. Hájek, V., and E. Marsalek. 1971. The differentiation of pathogenic staphylococci and a suggestion for their taxonomic classification. Zentralbl. Bakteriol. Parasitenkd. Infektionskr. Hyg. Abt. 1 Orig. Reihe A 217:176-182.

15. Hunter, D., J. N. Todd, and M. Larkin. 1970. Exudative epidermitis in pigs. The serological identification and distribution of the associated Staphylococcus. Br. Vet. J. 126:225-229.

16. Kloos, W. E., and K. H. Schleifer. 1975. Isolation and characterization of staphylococci from human skin. II. Descriptions of four new species: Staphylococcus warneri, Staphylococcus capitis, Staphylococcus hominis, and Staphylococcus simulans. Int. J. Syst. Bacteriol. 25:62-79.

17. Kloos, W. E., K. H. Schleifer, and R. F. Smith. 1976. Characterization of Staphylococcus sciuri sp. nov. and its subspecies. Int. J. Syst. Bacteriol. 26:22-37.

18. Kocur, M., and J. Boháček. 1974. DNA base composition and the classification of non-pigmented micrococci. Microbios 10A:31-38.

19. Lachica, R. V. F., P. D. Hoeprich, and C. Genigeorgis. 1971. Nuclease production and lysostaphin susceptibility of Staphylococcus aureus and other coagulase-positive cocci. Appl. Microbiol. 21:823-826.

20. Meyer, S. A., and K. H. Schleifer. 1975. Rapid procedure for the approximate determination of the deoxyribonucleic acid base composition of micrococci, staphylococci, and other bacteria. Int. J. Syst. Bacteriol. 25:383-385.

21. Sato, G., S. Miura, and N. Terakado. 1972. Classifica- tion of chicken coagulase-positive staphylococci into four biological types and relation to additional characteristics including coagulase antigenic type. Jpn. J. Vet. Res. 20:91-110

22. Schleifer, K. H., and M. Kocur. 1973. Classification of staphylococci based on chemical and biochemical properties. Arch. Mikrobiol. 93:65-85.

23. Schleifer, K. H., and W. E. Kloos. 1975. Isolation and characterization of staphylococci from human skin. I. Amended descriptions of Staphylococcus epidermidis and Staphylococcus saprophyticus and descriptions of three new species: Staphylococcus cohnii, Staphylococcus haemolyticus, and Staphylococcus xylosus. Int. J. Syst. Bacteriol. 25:50-61.

24. Smith, N. R., R. E. Gordon, and F. E. Clark. 1952. Aerobic sporeforming bacteria. U.S. Department of Agriculture monograph. no. 16. Taken from: R. S. Cowan [ed.], Cowan and Steel's manual for the identification of medical bacteria, Ind ed., p. 147, 1974, Cambridge University Press, London.

25. Sompolinsky, D. 1950 . Impetigo contagiosa suis. Maanedsskrift for Dyrlaeger 61:402-453.

26. Sompolinsky, D. 1953. De l'Inpetigo Contagiosa Suis et du Micrococcus hyicus n. sp. Schweiz. Arch. Tierheilkd. 95:302-309.

27. Stuker, G., and H. V. Bertschinger. 1976. Staphylococ cus hyicus: Kulturell-biochemische Charakterisierung, serologische Typisierung und Pathogenitätsnachweis im Tierversuch. Zentralbl. Veterinaermed. Reihe B 23:733-743.

28. Underdahl, N. R., O. D. Grace, and M. J. Twiehaus. 1965. Porcine exudative epidermitis: characterization of bacterial agent. Am. J. Vet. Res. 26:617-624.

29. Washington, J. A., II, and A. L. Barry. 1974. Dilution test procedures, p. 410-417, In E. H. Lennette, E. H. Spaulding, and J. P. Truant (ed.), Manual of clinical microbiology, 2nd ed. American Society for Microbiology, Washington, D.C.

30. Waterworth, P. M. 1948. Détection en culture primitive de la formation de pénicillinase. Ann. Inst. Pasteur (Paris) 75:94-96. 